\title{
Análise dos padrões de lançamento de efluentes em corpos hídricos e de reúso de águas residuárias de diversos estados do Brasil
}

\section{Analysis of effluent discharge standards in water bodies and reuse of wastewater from various Brazilian states}

\author{
Data de entrada: \\ 08/08/2017 \\ Data de aprovação: \\ $11 / 12 / 2017$
}

\section{Resumo}

O padrão de lançamento de efluentes em corpos hídricos é uma ferramenta que, juntamente com o padrão de qualidade dos corpos receptores e com o padrão de qualidade de águas residuárias para reúso, visa à preservação e conservação de fontes potáveis de água. Assim, o objetivo da presente contribuição é analisar os padrões de lançamento de efluentes em corpos hídricos e de reúso de águas residuárias de diversos estados do Brasil, de maneira a desenvolver um inventário dos padrões, estabelecer níveis de restrição e comparar os padrões estaduais de reúso com diretrizes e recomendações nacionais e internacionais usualmente utilizadas. Foram analisadas as legislações de dezesseis estados brasileiros e sete parâmetros de qualidade. Conclui-se que não há uma uniformização quanto à adoção de padrões de lançamento de efluentes e à não existência de um marco regulatório legal, em nível nacional, que estabeleça padrões e diretrizes para reúso de águas. Palavras-chave: Padrão de Lançamento de Efluentes. Padrão de Qualidade de Águas Residuárias para Reúso. Padrão de Qualidade dos Corpos Receptores.

\section{Abstract}

The standard for effluent discharge in water bodies is a tool which, together with the standard of quality of the receiving bodies and the wastewater quality standard for reuse, aims at the preservation and conservation of drinking water sources. Thus, the objective of the present contribution is to analyze the standards for effluent discharge in water bodies and wastewater reuse in several states of Brazil, in order to develop an inventory of the standards, establish restriction levels and compare the state reuse standards with commonly used national and international guidelines and recommendations. The legislations of sixteen Brazilian states and seven quality parameters were analyzed. It is concluded that there is no standardization regarding effluent discharge in water bodies and the absence of a legal regulatory framework at the national level that establishes standards and guidelines for water reuse. Keywords: Effluent discharge standards. Wastewater quality standard for reuse. Standard of quality of the receiving bodies. 


\section{INTRODUÇÃO}

O padrão de lançamento de efluentes em corpos hídricos é uma ferramenta que, juntamente com o padrão de qualidade dos corpos receptores, visa a resguardar a qualidade dos mananciais. As definições do tipo e da concentração do padrão de lançamento visam a facilitar a fiscalização dos poluidores e a detecção e autuação dos responsáveis pela degradação do corpo receptor (Von Sperling, 1998).

Em nível federal, o Conselho Nacional do Meio Ambiente (Conama), por meio de sua Resolução $n^{\circ}$ 430, de 13 de maio de 2011 (Brasil, 2011), dispõe sobre as condições e padrões de lançamento de efluentes, fixando valores de concentração de parâmetros orgânicos e inorgânicos a serem obedecidos por qualquer fonte poluidora que lance seus efluentes diretamente em corpos receptores.

Com efeito, alguns órgãos ambientais estaduais e municipais possuem legislações próprias sobre esse assunto, tendo como base os padrões estabelecidos pela legislação federal e, eventualmente, firmando padrões mais restritivos.

Geralmente os padrões de lançamento estão relacionados ao processo de licenciamento ambiental e de fiscalização de empreendimentos, principalmente de indústrias. Comumente são determinados pelas características e singularidades dos estados, principalmente devido aos fatores ambientais, como a qualidade dos mananciais, a vazão e a tipologia dos rios, a disponibilidade de água e de áreas, condições climáticas, e aos fatores econômicos, os quais podem influenciar no acesso às tecnologias de tratamento de efluentes.

Além dos padrões de lançamento de efluentes e do enquadramento dos corpos receptores, legalizado em nível federal pela Resolução Conama $n^{\circ} 357 / 2005$ (Brasil, 2005), os órgãos ambientais locais estão estudando e propondo padrões de qualidade de efluentes tratados para reúso não potável, legalizando, assim, mais uma ferramenta importante na gestão de recursos hídricos.
Segundo Mota et al. (2007), a utilização de esgotos tratados constitui uma medida efetiva de controle da poluição da água e uma alternativa para o aumento da oferta de água em regiões carentes de recursos hídricos.

Desse modo, o reúso de água planejado a partir de efluentes sanitários ou industriais tratados torna-se um recurso importante para a diminuição da exploração de mananciais e, consequentemente, para a redução da demanda de água bruta, pela substituição do uso de água potável por uma água de qualidade inferior.

Conforme Hespanhol (2003), cabe, entretanto, institucionalizar, regulamentar e promover o reúso de água no país, fazendo com que a prática se desenvolva de acordo com princípios técnicos adequados e seja economicamente viável, socialmente aceita e segura, em termos de preservação ambiental.

Dessa forma, é necessária uma legislação em nível federal que oriente a instituição das legislações estaduais e/ou municipais sobre padrões de reúso, visando uma uniformização de parâmetros e padrões, sendo respeitadas as singularidades locais e que assegure a qualidade físico-química e microbiológica das águas de reúso.

Assim, o objetivo da presente contribuição é analisar os padrões de lançamento de efluentes em corpos hídricos e de reúso de águas residuárias de diversos estados do Brasil, de maneira a desenvolver um inventário dos padrões, estabelecer níveis de restrição e comparar os padrões estaduais de reúso com diretrizes e recomendações nacionais e internacionais usualmente utilizadas.

\section{MATERIAL E MÉTODOS}

O levantamento das legislações ocorreu por meio de contato telefônico com os órgãos ambientais locais, consulta a artigos e trabalhos técnicos pertinentes ao assunto e por meio de sites de busca 
da internet. Dessa forma, promoveu-se a separação dos estados que possuem legislações sobre o tema abordado dos que não possuem e daqueles em que não foi possível obter tal informação.

Foram analisadas as legislações de dezesseis estados brasileiros, a saber: Amazônia, Roraima, Maranhão, Ceará, Pernambuco, Alagoas, Bahia, Mato Grosso do Sul, Goiás, Minas Gerais, Espírito
Santo, Rio de Janeiro, São Paulo, Paraná, Santa Catarina e Rio Grande do Sul (Figura 1).

Essas legislações foram comparadas com as Resoluções Conama n 20/1986, n 357/2005 e $n^{\circ} 430 / 2011$, as quais são marcos regulatórios federais que estabelecem padrões mínimos de qualidade dos efluentes para lançamento em corpos hídricos.

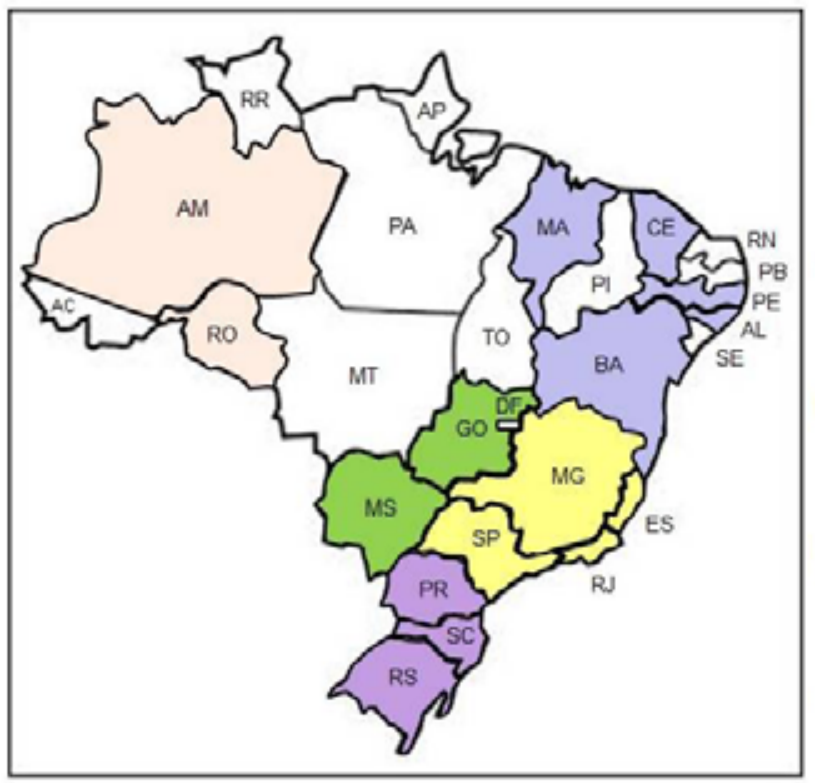

\section{Legenda}

Estados da Região Norte que possuem legislação sobre padrões de lançamento de efluentes.

Estados da Região Nordeste que possuem legislação sobre padrões de lançamento de efluentes.

Estados da Região Centro-Oeste que possuem legislação sobre padrões de lançamento de efluentes.

Estados da Região Sudeste que possuem legislação sobre padrões de lançamento de efluentes.

Estados da Região Sul que possuem legislação sobre padrōes de lançamento de efluentes.

Figura 1 - Estados brasileiros contemplados no inventário.

O estudo contempla os parâmetros e os padrões de lançamento de efluentes sanitários e industriais em comparação com a legislação federal vigente. Foram estudados sete parâmetros, a saber: Demanda Química de Oxigênio (DQQO), Demanda Bioquímica de Oxigênio (DBO), Sólidos Suspensos Totais (SST), Nitrogênio Total (N) e Amoniacal (NH3), Fósforo Total (P) e Coliformes Termotolerantes (C Term).

Esses padrões foram escolhidos por serem os principais indicadores de poluição dos recursos hídricos, sendo a avaliação e o monitoramento desses parâmetros fundamentais para o diagnóstico da qualidade das águas de um corpo receptor.
Adicionalmente, são os mais presentes nas legislações estudadas.

Além da análise comparativa das concentrações e dos padrões, realizou-se a quantificação dos parâmetros adotados em cada estado e das concentrações máximas mais utilizadas como padrões de lançamento de efluentes. Também se desenvolveu uma compilação e uma quantificação dos diversos tipos de lançamento permitidos nas legislações estudadas.

Por conseguinte, foram determinadas faixas de restrição, considerando os valores de concentrações que mais se repetem nas legislações. Os níveis de restrição permitem realizar uma análise compa- 
rativa entre os padrões de lançamento estaduais e identificar os estados que são mais e menos restritivos quanto ao descarte de efluentes.

Por fim, procedeu-se à comparação dos padrões utilizados pelos estados para reúso de efluentes sanitários com diretrizes e recomendações de programas nacionais de pesquisa, normas regulamentadoras e órgãos ambientais internacionais. Os parâmetros utilizados para essa discussão restringiram-se aos adotados pelas legislações estaduais devido aos objetivos deste artigo.

\section{RESULTADOS E DISCUSSÃO}

\subsection{Inventário de Padrões de Lançamento de Efluentes}

A Tabela 1 apresenta os estados que possuem legislação própria sobre lançamento de efluentes em corpos hídricos, correspondendo a 16 das 27 unidades federativas do país. Até onde se teve conhecimento, o Distrito Federal e os estados de Mato Grosso, Piauí, Paraíba e Pará não apresentam legislações vigentes sobre o tema.

De acordo com Jordão e Volschan Jr (2009), no estado da Paraíba, a Nota Técnica n 301/1988 estabelecia os padrões para lançamento de efluentes em corpos hídricos. Contudo, essa legislação não está mais em vigor, informação fornecida pelos órgãos ambientais desse estado. Além disso, não se obteve acesso a tal legislação para sua análise.

O Distrito Federal possui o Decreto $n^{\circ} 18.328$ de 1997, o qual determina os padrões de lançamento de efluentes líquidos na rede coletora de esgotos. No entanto, para o tratamento das águas residuárias e seu lançamento em corpos hídricos, a Companhia de Saneamento Ambiental do Distrito Federal - CAESB utiliza os padrões da Resolução Conama ${ }^{\circ} 430 / 2011$. Por isso, classificou-se o DF como não possuidor de legislação própria sobre o tema abordado.
Tabela 1 - Estados que possuem legislação sobre lançamento de efluentes.

\begin{tabular}{|c|c|c|}
\hline Legislação & Estados & Quantidade \\
\hline $\begin{array}{c}\text { Possuem } \\
\text { legislação própria }\end{array}$ & $\begin{array}{c}\text { SP, GO, SC, AL, RJ, ES (Vitória), } \\
\text { RO, BA, PE, RS, MA, MG, PR, AM } \\
\text { (Manaus), MS, CE. }\end{array}$ & 16 \\
\hline $\begin{array}{c}\text { Não possuem } \\
\text { legislação própria }\end{array}$ & MT, PI, PB, PA, DF. & 5 \\
\hline $\begin{array}{c}\text { Não se obteve } \\
\text { informação }\end{array}$ & AC, RR, AP, TO, RN,SE. & 6 \\
\hline
\end{tabular}

Não se obteve informação sobre a existência ou não de legislação específica sobre esse tema nos estados do Acre, Roraima, Amapá, Tocantins, Rio Grande do Norte e Sergipe. Logo, 59,3\% das unidades federativas possuem legislação própria, $18,5 \%$ não possuem e $22,2 \%$ muito provavelmente não possuem, pois não foi possível ter acesso a essa informação mesmo com consulta aos órgãos ambientais locais.

A Tabela 2 elenca as legislações brasileiras sobre lançamento de efluentes em corpos hídricos por ano de publicação.

Os estados de São Paulo, Goiás, Santa Catarina e Alagoas ainda possuem legislações vigentes anteriores às Resoluções do Conama. No entanto, verifica-se que estas adotam padrão de DBO mais restritivo em comparação com a Conama $n^{\circ}$ 430/2011. Além disso, a maioria das legislações estaduais anteriores a essa legislação federal adota mais parâmetros de qualidade do efluente para lançamento e padrões mais restritivos.

Assim, mesmo com as modificações e a inclusão de vários temas, como enquadramento de corpos hídricos, carga poluidora, eficiência mínima de remoção, ecotoxicidade e reúso, a legislação federal atual apresenta-se omissa quanto à adoção de limites para vários parâmetros de qualidade do efluente, como DQO, SST, P, e C Term.

Mesmo com os limites de fósforo e de coliformes nos padrões de classe estabelecidos pela Conama $n^{\circ} 357 / 2005$, muitos estados ainda não possuem enquadramento de seus corpos hídricos. 
Logo, a adoção de limites para esses parâmetros em legislação de lançamento de efluentes torna-se imprescindível.

Portanto, a atualização das legislações mais antigas torna-se importante devido à necessidade de revisão dos padrões e inclusão de novos padrões e conceitos antes pouco discutidos e analisados. Por exemplo, São Paulo, Santa Catarina e Goiás não adotam limites para DQO, SST e C Term, parâmetros verificados na maioria das legislações mais recentes sobre $o$ assunto.

Tabela 2 - Legislações nacionais sobre lançamento de efluentes em corpos hídricos.

\begin{tabular}{|c|c|c|}
\hline Estado/País & Legislação & Ano \\
\hline SP & Decreto $n^{\circ} 8.468$ & 1976 \\
\hline GO & Decreto $n^{\circ} 1.745$ & 1979 \\
\hline SC & Decreto $n^{\circ} 14.250$ & 1981 \\
\hline $\mathrm{AL}$ & Decreto $n^{\circ} 6.200$ & 1985 \\
\hline BRASIL & Resolução Conama n 20 & 1986 \\
\hline $\mathrm{RJ}$ & $\begin{array}{c}\text { Deliberação CECA n 1007: NT } \\
\text { FEEMA 202.R10 }\end{array}$ & 1986 \\
\hline PB & NT $n^{\circ} 301$ & 1988 \\
\hline ES & Resolução Comdema n ${ }^{\circ} 02$ & 1991 \\
\hline RO & Decreto $n^{\circ} 7.903$ & 1997 \\
\hline $\mathrm{BA}$ & Resolução Cepram n 2.228 & 2000 \\
\hline $\mathrm{PE}$ & NT n² 2001 e NT n² 2002 da CPRH & $2001 / 2002$ \\
\hline BRASIL & Resolução Conama nº 357 & 2005 \\
\hline RS & Resolução Consema n 128 & 2006 \\
\hline PE & NT n² 2007 da CPRH & 2007 \\
\hline MG & $\begin{array}{c}\text { Deliberação Normativa Conjunta } \\
\text { Copam/CERH n }{ }^{\circ} 01\end{array}$ & 2008 \\
\hline PR & $\begin{array}{c}\text { Resolução SEMA n } 21 \text { e Resolução } \\
\text { Cema n }{ }^{\circ} 70\end{array}$ & 2009 \\
\hline BRASIL & Resolução Conama n 430 & 2011 \\
\hline AM & Resolução Comdema n 34 & 2012 \\
\hline MS & Deliberação Ceca n 36 & 2012 \\
\hline MA & Portaria Sema nº 79 & 2013 \\
\hline MT & $\begin{array}{l}\text { Resolução CONSEMA n } 55 \text { e } \\
\text { Resolução Consema n } 90\end{array}$ & $2012 / 2013$ \\
\hline CE & Resolução Coema nº 02 & 2017 \\
\hline
\end{tabular}

Como resultado da compilação das legislações consultadas, apresenta-se um Inventário de Padrões de Lançamento de Efluentes nas Tabelas 3 A e 3 B.

Para o parâmetro de DBO, a maioria dos estados utiliza valores mais restritivos do que a preconizada pela Resolução Conama n 430/2011, destacando-se Pernambuco, Rio de Janeiro e Rio Grande do Sul, que são flexíveis em função da grandeza da poluição, isto é, variam de acordo com a vazão ou carga do poluente e não em termos de concentração.

Segundo Veról e Volschan Jr. (2011), a flexibilidade em relação à grandeza da poluição considera que, quanto menor for a geração de carga orgânica, menor será a eficiência de remoção requerida, e maior será a concentração admissível no efluente.

Adotar padrões em termos de concentração é uma interrelação entre os padrões de lançamento de efluentes e os padrões de qualidade dos corpos hídricos. No entanto, verifica-se que esse mecanismo não promove a diferenciação de pequenos (baixa vazão) e grandes poluidores (alta vazão). Dessa forma, o pequeno poluidor possui dificuldades de provar sua menor participação na degradação dos mananciais, devendo se adequar aos mesmos padrões empregados para os grandes poluidores.

Destaca-se que a adoção de padrões de lançamento tendo como base a carga poluidora presente nos efluentes tem fundamento legal nos artigos $7^{\circ}$ e $28^{\circ}$ da Resolução Conama n ${ }^{\circ} 430 / 2011$ e que pode ser um mecanismo útil para o controle do lançamento de cargas orgânicas e, consequentemente, para o monitoramento da qualidade dos corpos receptores. 
Tabela 3 A-Inventário de Padrões de Lançamento de Efluentes.

\begin{tabular}{|c|c|c|c|c|c|c|c|c|c|c|}
\hline \multirow[b]{2}{*}{ Estados } & \multirow[b]{2}{*}{ Legislação } & \multicolumn{6}{|c|}{$\begin{array}{c}\text { Padrões de Lançamento de Efluentes em Corpos Hídricos } \\
\text { Concentrações Exigidas nos Efluentes }\end{array}$} & \multicolumn{3}{|c|}{ Eficiência de Remoção (\%) } \\
\hline & & $\begin{array}{l}\text { DQO } \\
\left(\mathrm{mg} \mathrm{O}_{2} / \mathrm{L}\right)\end{array}$ & $\begin{array}{l}\mathrm{DBO} \\
\left(\mathrm{mg} \mathrm{O}_{2} / \mathrm{L}\right)\end{array}$ & $\begin{array}{l}\mathrm{SST} \\
(\mathrm{mg} / \mathrm{L})\end{array}$ & $\stackrel{\mathrm{N}}{\mathrm{N}}$ & $\underset{(m g / L)}{P}$ & $\begin{array}{l}\text { C Term } \\
\text { (NMPI } \\
100 \mathrm{~mL})\end{array}$ & DQQO & DBO & SST \\
\hline $\begin{array}{c}\text { AM } \\
\text { (Manaus) }\end{array}$ & $\begin{array}{c}\text { Resolução } \\
\text { Comdema } \\
34 / 2012\end{array}$ & $\begin{array}{l}100^{(18)} \\
150^{(5)}\end{array}$ & $\begin{array}{l}60^{(18)} \\
90^{(5)}\end{array}$ & $\begin{array}{l}100^{(1)} \\
60^{(2)}\end{array}$ & - & - & - & - & $\begin{array}{l}75^{(18)} \\
85^{(5)}\end{array}$ & $20^{(19)}$ \\
\hline RO & $\begin{array}{l}\text { Decreto } \\
7.903 / 1997\end{array}$ & - & - & - & $5^{(3)}$ & - & - & - & - & - \\
\hline$A L$ & $\begin{array}{l}\text { Decreto } \\
6.200 / 1985\end{array}$ & 150 & 60 & - & $0,5^{(3)}$ & - & - & - & - & - \\
\hline BA & $\begin{array}{l}\text { Resolução Cepram } \\
2.228 / 2000\end{array}$ & - & - & - & - & - & 106 & - & $80-95^{(4)}$ & $\begin{array}{l}70- \\
90^{(4)}\end{array}$ \\
\hline CE & $\begin{array}{l}\text { Resolução Coema } \\
\text { 02/2017 }\end{array}$ & $\begin{array}{l}200^{(18)(20)} \\
600^{(21)}\end{array}$ & $120^{(5)}$ & $\begin{array}{c}100^{(5)(18)(20)} \\
150^{(6)(21)}\end{array}$ & $\begin{array}{c}5^{(3)(18)} \\
20^{(3)(7)(18)(21)}\end{array}$ & - & 5000 & - & - & $20^{(19)}$ \\
\hline MA & $\begin{array}{c}\text { Portaria Sema } \\
79 / 2013\end{array}$ & - & - & - & - & - & - & - & 90 & 90 \\
\hline PE & $\begin{array}{c}\text { NT 2001/2002/ } \\
2007 \text { da CPRH }\end{array}$ & $\begin{array}{c}360(C \leq 2)(8)(18) \\
160(2<C \leq 6) \\
120(6<C \leq 50) \\
60(C>50)\end{array}$ & $\begin{array}{c}180(C \leq 2)(8)(18) \\
80(2<C \leq 6) \\
60(6<C \leq 50) \\
30(C>50)\end{array}$ & - & - & - & $\begin{array}{l}\text { De } 10^{6} \mathrm{a} \\
10^{4(9)}\end{array}$ & $60-90^{(10)(18)}$ & $\begin{array}{c}40(C \leq 2)^{(8)}(18) \\
70(2<C \leq 6) \\
80(6<C \leq 50) \\
90(C>50)\end{array}$ & - \\
\hline GO & $\begin{array}{c}\text { Decreto } \\
1.745 / 1979 \\
\text { Regulamento }\end{array}$ & - & 60 & - & - & - & - & - & 80 & - \\
\hline MS & $\begin{array}{c}\text { Deliberação Ceca } \\
36 / 2012\end{array}$ & - & $\begin{array}{l}100^{(18)} \\
120^{(5)}\end{array}$ & - & $20^{(3)(11)(18)}$ & - & - & - & $\begin{array}{l}90^{(18)} \\
80^{(5)}\end{array}$ & - \\
\hline BRASIL & $\begin{array}{c}\text { Conama } \\
430 / 2011\end{array}$ & - & $120^{(5)}$ & - & $20^{(3)(5)(11)(18)}$ & - & - & - & $60^{(5)(18)}$ & - \\
\hline
\end{tabular}

Tabela 3 B - Inventário de Padrões de Lançamento de Efluentes.

\begin{tabular}{|c|c|c|c|c|c|c|c|c|c|c|}
\hline & & Padrõ & $\begin{array}{l}\text { S de Lançan } \\
\text { Concentr }\end{array}$ & $\begin{array}{l}\text { ento de E } \\
\text { ç̧ões Exig }\end{array}$ & $\begin{array}{l}\text { las nos Efluent } \\
\text { las em Cor }\end{array}$ & os Hídricos & & Eficiê & ncia de Remoçã & (\%) \\
\hline Estados & Legislação & $\begin{array}{c}\text { DQO } \\
\left.\text { (mg O }{ }_{2} / \mathrm{L}\right)\end{array}$ & $\begin{array}{c}\text { DBO } \\
\left(\mathrm{mg} \mathrm{O}_{2} / \mathrm{L}\right)\end{array}$ & $\begin{array}{c}\text { SST } \\
\text { (mg/L) }\end{array}$ & $\underset{(m g-N / L)}{N}$ & $\begin{array}{c}P \\
(m g / L)\end{array}$ & $\begin{array}{l}\text { C Term } \\
\text { (NMP/ } \\
100 \mathrm{~mL})\end{array}$ & DQQ & DBO & SST \\
\hline $\begin{array}{c}\text { ES } \\
\text { (Vitória) }\end{array}$ & $\begin{array}{c}\text { Resolução } \\
\text { Comdema } \\
02 / 1991\end{array}$ & 200 & - & 100 & $5^{(3)}$ & - & - & - & $\begin{array}{c}90 \\
(C \geq 100)^{(8)}\end{array}$ & - \\
\hline MG & $\begin{array}{c}\text { Deliberação } \\
\text { Normativa } \\
\text { Conjunta } \\
\text { Copam/CERH } \\
01 / 2008\end{array}$ & $\begin{array}{c}180 \\
250^{(12)}\end{array}$ & 60 & $\begin{array}{c}100 \\
150^{(6)}\end{array}$ & $5^{(3)(11)}$ & - & - & 70 & 75 & - \\
\hline RJ & $\begin{array}{c}\text { Deliberação } \\
\text { Ceca n 1007/86 } \\
\text { - NT FEEMA } 202 . \\
\text { R10/1986 }\end{array}$ & - & $\begin{array}{r}180(C \\
100(5< \\
65(25< \\
40(C\end{array}$ & $\begin{array}{l}5)^{(8)} \\
\leq 25) \\
\leq 80) \\
80)\end{array}$ & $10^{5^{(3)}}$ & $1^{(13)}$ & - & - & $\begin{array}{c}30(C \leq 5)^{(8)} \\
65(5<C \leq 25) \\
80(25<C \\
\leq 80) \\
85(C>80)\end{array}$ & - \\
\hline PR & $\begin{array}{c}\text { Resolução Sema } \\
\text { 21/2009 e } \\
\text { Resolução Cema } \\
70 / 2009\end{array}$ & $\begin{array}{c}225 \\
200^{(10)(14)}\end{array}$ & $\begin{array}{c}90 \\
50^{(14)}\end{array}$ & - & - & - & - & - & - & - \\
\hline RS & $\begin{array}{l}\text { Resolução } \\
\text { Consema } \\
128 / 2006\end{array}$ & $\begin{array}{c}400(Q<20)^{(15)} \\
360(20 \leq Q<100) \\
330(100 \leq Q<500) \\
300(500 \leq Q<1000) \\
260(1000 \leq Q<3000) \\
200(3000 \leq Q<7000) \\
180\left(7000 \leq Q<10^{4}\right) \\
150\left(Q \geq 10^{4}\right)\end{array}$ & $\begin{array}{r}180(Q \\
150(20 \leq \\
110(100 \leq \\
80(500 \leq \\
70(1000 \leq \\
60(3000 \leq \\
50(7000 \leq \\
40(Q\end{array}$ & $\begin{array}{l}20)^{(15)} \\
?<100) \\
Q<500) \\
<1000) \\
(<3000) \\
2<7000) \\
\left.Q<10^{4}\right) \\
\left.10^{4}\right)\end{array}$ & $\begin{array}{c}20(Q<100) \\
(15)(16) \\
20(100<Q \\
\left.\leq 10^{3}\right) \\
15\left(10^{3}<Q \leq\right. \\
\left.10^{4}\right) \\
10\left(Q \geq 10^{4}\right) \\
20^{(3)}\end{array}$ & 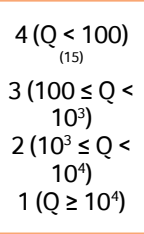 & $\begin{array}{c}105(\mathrm{Q}< \\
100)^{(15)} \\
104(100 \leq \mathrm{Q} \\
\left.<10^{3}\right) \\
104\left(10^{3} \leq \mathrm{Q}\right. \\
\left.<10^{4}\right) \\
103\left(\mathrm{Q} \geq 10^{4)}-\right.\end{array}$ & - & - & - \\
\hline SC & $\begin{array}{c}\text { Decreto } \mathrm{N}^{\circ} \\
14.250 / 1981 \mathrm{e} \\
\text { Lei } 14.675 / 2009\end{array}$ & - & 60 & - & $10^{(13)(16)}$ & $4^{(13)(17)}$ & - & -- & 80 & - \\
\hline BRASIL & $\begin{array}{c}\text { Conama } \\
430 / 2011\end{array}$ & - & $120^{(5)}$ & - & $20^{(3)(5)(11)(18)}$ & - & - & - & $60^{(5)(18)}$ & - \\
\hline
\end{tabular}


1. Valor Máximo Diário.

2. Média Aritmética Mensal.

3. Nitrogênio Amoniacal.

4. Variável de acordo com o padrão socioeconômico do empreendimento imobiliário habitacional.

5. Para efluentes sanitários (domésticos).

6. Para efluentes de Lagoas de Estabilização.

7. Somente para pH abaixo de 8 (Resolução Coema n ${ }^{02} / 2017$ ).

8. Variável de acordo com a Carga Orgânica diária bruta (kg/dia).

9. Variável de acordo com classes de enquadramento do corpo d'água receptor.

10. De acordo com o Tipo de Indústria.

11. O padrão para Nitrogênio Amoniacal não é exigivel para Sistemas de Tratamento de Esgotos Sanitários e deve atender ao padrão da classe de enquadramento do corpo receptor.

12. Para Indústria Têxtil.

13. Lançamentos em Corpos Hídricos contribuintes de lagoas ou lagunas ou estuários.

14. Pra Indústrias de Laticínios.

15. Variável de acordo com a Vazão diária (m3/dia).

16. Nitrogênio Total.

17. A legislação prevê eficiência mínima de remoção de $75 \%$.

18. Para efluentes industriais.

19. A legislação prevê eficiência mínima de remoção após desarenação, em casos de lançamento de efluentes por meio de emissário submarino.

20. Para efluentes advindos de lavagem de filtro de ETA.

21. Para lançamento indireto de efluentes (em sistema coletor das operadoras de serviços de esgoto).

Por intermédio do inventário, constata-se que, para o parâmetro de DQQO, as legislações estaduais empregam valores de concentrações bem distintos, sem apresentar um padrão característico. Além disso, a legislação federal não apresenta um valor teto a ser cumprido, aumentando a autonomia dos estados e possibilitando que estes adotem padrões que se adequem mais ao seu contexto ambiental e econômico.

Dessa forma, verifica-se que a maioria dos estados adota padrões de DOO para efluentes industriais e sanitários, além de estabelecer concentrações próprias de acordo com a tipologia industrial ou do empreendimento, como no caso do Ceará, de Minas Gerais e do Paraná. Apenas dois estados adotam padrões de DQO de acordo com a variação da carga poluidora, a saber, Pernambuco e Rio Grande do Sul.

Em relação ao parâmetro de sólidos suspensos totais (SST), há uma diversidade de padrões fixados, possivelmente por não existir uma concentração limite na legislação federal. Apenas seis estados brasileiros adotam esse parâmetro para verificação em caso de lançamento de efluentes, sendo comum a concentração limite de 100 mgSST/L.
O município de Manaus, por exemplo, admite uma concentração diária de $100 \mathrm{mgSST} / \mathrm{L}$ e uma concentração média mensal de $60 \mathrm{mgSST} / \mathrm{L}$. Essa abordagem é interessante devido a possíveis variações desse parâmetro em estações de tratamento de esgotos causadas por fatores externos, como chuvas, que podem carrear material particulado para dentro do sistema de tratamento, ou por outros fatores, como falha operacional, produção excessiva de lodo e variação na carga poluidora presente no efluente a ser tratado. Logo, essa flexibilidade em relação à concentração diária e mensal permite uma menor restrição e uma maior facilidade em atender a legislação.

No Ceará, é adotada a concentração de 100 mgSST/L para efluentes sanitários, industriais e advindos de lavagem de filtro de ETA e a concentração de $150 \mathrm{mgSST} / \mathrm{L}$ para lançamento em sistema coletor das operadoras de serviço de esgotos e para efluentes advindos de lagoas de estabilização, os quais, geralmente, possuem elevada concentração de sólidos suspensos devido à presença de biomassa. Essa diferenciação de concentrações que considera o tipo de tratamento facilita o atendimento dos padrões e, consequentemente, o cumprimento legal pelos grandes e pequenos poluidores. 
Para os parâmetros de DQO, DBO e SST, alguns estados e a Resolução Conama $n^{\circ}$ 430/2011 firmam padrões de eficiência mínima de remoção em estações de tratamento, visando a garantir um mínimo de qualidade ao efluente. No entanto, essa metodologia pode não ser eficaz em casos de tratamento de esgotos com elevada carga poluidora e não assegura a geração de um efluente com concentrações aceitáveis para lançamento em corpos receptores.

O estado da Bahia, por meio da Resolução Cepram $n^{\circ} 2.288 / 2000$, adota eficiências mínimas de remoção de DBO na faixa de $80 \%$ a $95 \%$ de acordo com o perfil socioeconômico de empreendimentos habitacionais.

Essa forma de exigir o tratamento dos esgotos, apesar de não assegurar um efluente com características aceitáveis para o lançamento em corpos hídricos, apresenta-se como um esforço legal para o controle da poluição, mas não contribui de forma eficaz para diminuir os efeitos adversos ocasionados ao meio ambiente pelo lançamento de efluentes com baixa qualidade em mananciais, pois o impacto ambiental ocorrerá independentemente do padrão socioeconômico de um grupo de pessoas, devido à semelhança da composição dos esgotos domésticos.

Constata-se que todas as legislações estaduais que aplicam eficiência mínima de remoção de DBO são mais restritivas do que a legislação federal, a qual estabelece remoção mínima de $60 \%$, enquanto os estados exigem valores na faixa de $75 \%$ a $95 \%$.

Em relação aos nutrientes, o parâmetro nitrogênio total é solicitado no Rio de Janeiro, no Rio Grande do Sul e em Santa Catarina, sendo a concentração máxima de $10 \mathrm{mgN} / \mathrm{L}$ a mais utilizada. O estado do Rio Grande do Sul utiliza a variação da carga poluidora de nitrogênio total como padrão de lançamento, mas também adota a concentra- ção de 20 mg-N/L como valor limite de nitrogênio amoniacal nos efluentes.

O nitrogênio amoniacal é utilizado por nove estados, sendo $5 \mathrm{mg}-\mathrm{N} / \mathrm{L}$ e $20 \mathrm{mg}-\mathrm{N} / \mathrm{L}$ as concentrações mais representativas, sendo mais adotado pelos estados do que o parâmetro de nitrogênio total. Isso pode ser explicado pelo maior efeito nocivo da amônia no meio ambiente, principalmente em sua forma não ionizada (NH3).

Erickson (1985) reporta que, embora alguma toxicidade possa ser atribuída à amônia ionizada, a forma não ionizada é reconhecidamente a espécie mais tóxica de amônia. Dessa forma, o controle desse parâmetro torna-se fundamental para a conservação e preservação dos mananciais.

Logo, torna-se importante observar a legislação do Ceará, a qual adere padrão para nitrogênio amoniacal apenas para efluentes industriais e varia de acordo com o $\mathrm{pH}$ do efluente. Para valores de $\mathrm{pH}$ abaixo de 8 , o valor máximo permitido é de $20 \mathrm{mg}$ -N/L, e, para valores de $\mathrm{pH}$ acima de 8 , a concentração máxima nos efluentes é de 5 mg-N/L.

A legislação federal e a de Minas Gerais também aplicam a concentração de $20 \mathrm{mg}-\mathrm{N} / \mathrm{L}$, no entanto, assim como no Ceará, esse parâmetro não é exigível para Sistemas de Tratamento de Esgotos Sanitários.

Percebe-se que as legislações desses estados e a Resolução Conama $n^{\circ}$ 430/11 suprimem a responsabilidade das Companhias e Agências de tratamento de esgotos públicos, mas exigem das indústrias e de outros empreendimentos privados o cumprimento do padrão de nitrogênio amoniacal. Essa medida apresenta-se contraditória em termos de geração de impacto ambiental, pois é notável que os esgotos públicos tratados correspondem a uma elevada parcela da carga poluidora lançada em mananciais, principalmente, devido à elevada vazão de descarte. 
Ressalta-se que adotar uma concentração de 5 $\mathrm{mg}-\mathrm{N} / \mathrm{L}$ de amônia em efluentes industriais com $\mathrm{pH}$ acima de 8 , critério utilizado no Ceará, torna-se impeditivo à adoção de determinadas tecnologias de tratamento, como o sistema de lagoas de estabilização.

Segundo Von Sperling (2005), a fotossíntese que ocorre nas lagoas facultativas e, principalmente, nas lagoas de maturação, de polimento e de alta taxa, contribui para a elevação do $\mathrm{pH}$, por retirar do meio líquido o $\mathrm{CO}_{2}$, ou seja, a acidez carbônica. Adicionalmente, em lagoas de maturação, um dos fatores que contribuem para a inativação de microrganismos é um $\mathrm{pH}$ elevado comumente acima de 8,5.

Ainda conforme o mesmo autor, um sistema de tratamento de efluentes sanitários composto por lagoa anaeróbia, lagoa facultativa e lagoas de maturação possui a capacidade de gerar efluentes com concentração entre $10 \mathrm{mg}-\mathrm{N} / \mathrm{L}$ a $15 \mathrm{mg}$ -N/L de amônia, possuindo uma eficiência média de remoção na faixa de $50 \%$ a $65 \%$.

Logo, esse tipo de tecnologia para tratamento de efluentes dificilmente atenderia a esse limite tão restritivo. Conforme observaram Reis (1998), Reis e Mendonça (1998; 1999A; 1999B; 2009), o limite de $5 \mathrm{mg}-\mathrm{N} / \mathrm{L}$ para as concentrações de amônia total nos efluentes apresenta-se extremamente rigoroso.

A obtenção de 20 mg-N/L de nitrogênio amoniacal para alguns efluentes industriais, mesmo a partir do uso de processos anaeróbios-aeróbios como UASB-FSA, UASB-FBP ou UASB-Wetlands, é bem difícil, necessitando-se muitas vezes de processos terciários de tratamento de esgotos. Assim, os custos de implantação, operação e manutenção serão muito elevados, inviabilizando o cumprimento da legislação por parte de muitas indústrias de pequeno e médio portes.
No que se refere ao parâmetro fósforo, apenas três estados utilizam padrão de lançamento. Os estados de Rio de Janeiro e Santa Catarina estabelecem concentrações máximas para o lançamento de fósforo em corpos hídricos contribuintes de lagoas, lagunas ou estuários. Essa medida visa a evitar a eutrofização de ecossistemas de água doce lênticos e a ação nociva desse poluente à biodiversidade dos estuários.

No que concerne ao parâmetro de coliformes termotolerantes, apenas quatro dos dezesseis estados empregam padrões para lançamento. Ressalta-se o padrão adotado por Pernambuco, o qual diversifica a quantidade de coliformes em consonância com a classe de enquadramento do corpo de água receptor. Nota-se que o padrão de 106 NMP/100 mL, aplicado na Bahia para empreendimentos imobiliários habitacionais, é a concentração mais permissiva em comparação com os outros estados que utilizam esse parâmetro.

A Tabela 4 apresenta os parâmetros adotados por cada estado e as concentrações mais utilizadas como padrões de lançamento de efluentes. Percebe-se que a concentração máxima de DOQO é aderida por oito estados, contudo os padrões são diversos, não existindo um valor característico ou representativo.

Além disso, verifica-se que a maior parcela dos estados adota padrões para DBO, SST, NH3, sendo $60 \mathrm{mgO}_{2} / \mathrm{L}, 100 \mathrm{mgSST} / \mathrm{L}$ e $5 \mathrm{mg}-\mathrm{N} / \mathrm{L}$, respectivamente, as concentrações máximas mais representativas desses parâmetros.

A concentração de $60 \mathrm{mg} \mathrm{O} / \mathrm{L}$ de DBO, sendo a mais adotada como padrão de lançamento de efluentes, também foi verificada por Von Sperling \& Nascimento (1999), os quais realizaram uma análise dos padrões de 14 estados brasileiros, e por Veról e Volschan Jr. (2011), os quais verificaram 15 legislações estaduais sobre lançamento de efluentes. 
Os tipos de lançamento de efluentes apresentados nas legislações estudadas podem ser observados na Tabela 5. Constata-se que apenas Ceará e Minas Gerais determinam padrões específicos e menos restritivos para Lagoas de Estabilização, tecnologia muito utilizada nesses estados devido à disponibilidade de área e baixo custo operacional. Essa adoção visa facilitar o cumprimento das legislações no que concerne ao parâmetro de sólidos suspensos totais (SST), o qual costuma ser elevado nesse tipo de tratamento devido à presença de biomassa suspensa.

Em relação à disposição no solo de efluentes, apenas as legislações do Ceará e do Mato Grosso do Sul estabelecem padrões específicos. Nos demais estados, a legislação apenas registra que a disposição de efluentes no solo, mesmo tratados, não poderá causar poluição ou contaminação das águas.

No tocante ao lançamento de efluentes na rede coletora municipal, apenas seis das legislações estudadas determinam padrões específicos. Além disso, em relação aos parâmetros estudados, apenas o Ceará estabelece padrão de DBO para lançamento na rede coletora.

É importante ressaltar que isso não indica que os outros estados analisados nesse estudo não possuam padrões para esse tipo de lançamento, mas que os parâmetros diferem dos analisados nesse estudo ou que as legislações específicas não foram encontradas.

Por exemplo, Goiás possui uma legislação própria para lançamento em corpos hídricos (Decreto Estadual $\left.n^{\circ} 1.745 / 1979\right)$ e um Regulamento da Companhia de Desenvolvimento Econômico de Goiás (Regulamento Codego-AGE de 08/07/2016), que definem padrões de lançamento na rede coletora para indústrias localizadas nos distritos industriais.

No entanto, em alguns estados existe apenas uma legislação que estabelece os tipos de lançamento de efluentes e seus padrões, como a Resolução Coema nº 02/2017 do Ceará. Essa legislação contempla padrões para lançamento em corpos hídricos, em lagoas de estabilização, em rede coletora municipal, em emissário submarino e no solo, além de definir padrões para efluentes de lavagem de filtros de Estação de Tratamento de Águas e para a prática do reúso de efluentes sanitários.

Portanto, verifica-se a existência de vários tipos de lançamento de efluentes, determinados principalmente segundo as necessidades e critérios de cada estado, como tecnologia de tratamento de efluentes acessível, clima, condições do solo, possibilidade de lançamento de efluentes no mar, presença de distritos industriais e o enfrentamento de escassez hídrica.

Tabela 4 - Concentração Máxima dos Parâmetros mais adotada pelos estados.

\begin{tabular}{|c|c|c|c|}
\hline Parâmetro & $\begin{array}{l}\text { Adotam } \\
\text { Concentração } \\
\text { Máxima }\end{array}$ & $\begin{array}{l}\text { Adotam } \\
\text { Eficiência } \\
\text { Mínima de } \\
\text { Remoção }\end{array}$ & $\begin{array}{l}\text { Concentração } \\
\text { mais Adotada }\end{array}$ \\
\hline \multirow{2}{*}{$\begin{array}{c}\text { DQO } \\
\left(\mathrm{mg} \mathrm{O}_{2} / \mathrm{L}\right)\end{array}$} & $\mathbf{8}^{(1)}$ & $\mathbf{2}^{(2)}$ & - \\
\hline & $\begin{array}{c}\text { AM, AL, CE, PE, ES, } \\
\text { MG, PR, RS, SC }\end{array}$ & PE, MG & $-(3)$ \\
\hline \multirow[b]{2}{*}{$\begin{array}{c}\text { DBO } \\
\left(\mathrm{mg} \mathrm{O}_{2} / \mathrm{L}\right)\end{array}$} & 12 & 11 & $9^{(4)}$ \\
\hline & $\begin{array}{c}\text { AM, AL, CE, PE, GO, } \\
\text { MS, MG, RJ, SP, PR, } \\
\text { RS, SC }\end{array}$ & $\begin{array}{l}\text { AM, BA, MA, } \\
\text { PE, GO, MS, ES, } \\
\text { MG, RJ, SP, SC }\end{array}$ & 60 \\
\hline \multirow[b]{2}{*}{$\begin{array}{c}\text { SST } \\
(\mathrm{mg} / \mathrm{L})\end{array}$} & 6 & 5 & 5 \\
\hline & $\begin{array}{c}\text { AM, CE, ES, MG, } \\
\text { RJ, RS }\end{array}$ & $\begin{array}{c}\text { AM, BA, CE, } \\
\text { MA, RJ }\end{array}$ & 100 \\
\hline \multirow{2}{*}{$\begin{array}{l}\text { N Total } \\
(\mathrm{mg} / \mathrm{L})\end{array}$} & 3 & 1 & 3 \\
\hline & RJ, RS, SC & RS & 10 \\
\hline \multirow{2}{*}{$\underset{(\mathrm{mg}-\mathrm{N} / \mathrm{L})}{\mathrm{NH}_{3}}$} & 9 & - & 5 \\
\hline & $\begin{array}{c}\text { RO, AL, CE, MS, ES, } \\
\text { MG, RJ, RS, SC }\end{array}$ & - & 5 \\
\hline \multirow{2}{*}{ P Total (mg/L) } & 3 & 1 & 2 \\
\hline & RJ, RS, SC & $\mathrm{SC}$ & 4 \\
\hline \multirow{2}{*}{$\begin{array}{c}\text { C Term } \\
\text { (NMP/100mL) }\end{array}$} & 4 & 1 & - \\
\hline & BA, CE, PE, RS & RS & - \\
\hline
\end{tabular}

1. Número de estados que adotam limites de concentração máxima.

2. Número de estados que adotam limites de eficiência mínima de remoção.

3. O parâmetro não possui valor representativo de concentração mais adotado.

4. Número de estados que adotam o valor representativo de concentração mais utilizado. 
Tabela 5 - Tipologia de Lançamento de Efluentes.

\begin{tabular}{|c|c|}
\hline \multicolumn{2}{|c|}{ Adotam Padrões de Lançamento: } \\
\hline $\begin{array}{c}\text { Para Efluentes Oriundos de } \\
\text { Sistemas de } \\
\text { Lagoas de Estabilização }\end{array}$ & $\begin{array}{c}\text { Para Descarte de Efluentes } \\
\text { por meio de Emissário } \\
\text { Submarino }\end{array}$ \\
\hline (1) & $\mathbf{4}$ \\
\hline $\begin{array}{c}\text { CE, MG } \\
\text { Para Descarte de Efluentes em } \\
\text { Sistemas de Esgotos } \\
\text { providos de Tratamento } \\
\text { (Rede Coletora) }\end{array}$ & AM, AL, CE, ES \\
\hline $\mathbf{6}$ & $\begin{array}{c}\text { Para Disposição de Efluentes } \\
\text { no Solo }\end{array}$ \\
\hline $\begin{array}{c}\text { RO, CE, GO, ES, RJ, SP } \\
\text { Para Lavagem de Filtro de ETA }\end{array}$ & $\mathbf{2}$ \\
\hline $\mathbf{1}$ & Para Águas de Reúso \\
\hline CE & $\mathbf{2}$ \\
\hline $\begin{array}{c}\text { Segundo a Tipologia Industrial } \\
\text { ou do Empreendimento }\end{array}$ & Segundo a Carga Poluidora \\
\hline $\mathbf{3}$ & $\mathbf{3}$ \\
\hline CE, PE, PR & PE, RJ, RS \\
\hline
\end{tabular}

1. Número de estados que adotam padrões para determinada tipologia de lançamento de efluentes.

\subsection{Niveis de Restrição dos Padrões de Lançamento}

Com base nas legislações estaduais apresentadas, a Tabela 6 apresenta os níveis de restrição de acordo com a concentração dos parâmetros nos efluentes. Ressalta-se que essa tabela foi desenvolvida apenas com os padrões de lançamento em corpos hídricos, excluindo-se os outros tipos de lançamento.

Dentre os estados considerados muito restritivos estão Pernambuco, Rio de Janeiro e Rio Grande do Sul, os quais diversificam as concentrações em função da carga ou da vazão. Por isso, também estão enquadrados nas outras categorias.

Nesse contexto, Alagoas também é considerado muito restritivo por decretar que a concentração máxima de nitrogênio amoniacal em lançamen- tos de efluentes é de 0,5 mg-N/L. Esse padrão apresenta-se muito restritivo e não é representativo quando comparado com os outros padrões aderidos por outros estados brasileiros, além de dificultar o atendimento à legislação.

A legislação do município de Manaus também é considerada muito restritiva no que se refere ao padrão de Sólidos Suspensos Totais, adotando um valor médio mensal de $60 \mathrm{mg} / \mathrm{L}$. Também considerado muito restritivo, o Ceará é muito rigoroso quanto ao parâmetro de coliformes termotolerantes.

Além dos estados que são considerados menos restritivos devido à diversificação da concentração de acordo com a carga ou vazão do efluente, Minas Gerais e do Paraná são menos restritivos em relação ao parâmetro de DQQ, admitindo valores de concentrações superiores a 200 mg/L.

No que diz respeito ao parâmetro fósforo, Santa Catarina e Rio Grande do Sul são considerados menos restritivos devido à adoção de uma concentração máxima de $4 \mathrm{mg} / \mathrm{L}$ e à variação da concentração máxima segundo a vazão diária de lançamento, respectivamente.

Em relação aos coliformes termotolerantes, Pernambuco é classificado como menos restritivo e aplica padrões de acordo com o enquadramento do corpo receptor. $O$ estado do Ceará apresenta o valor mais restritivo para esse parâmetro, determinando $5000 \mathrm{NMP} / 100 \mathrm{~mL}$. Os estados mais permissivos no tocante ao lançamento de coliformes termotolerantes são Bahia, Pernambuco e Rio Grande do Sul. 
Tabela 6 - Níveis de Restrições dos Padrões de Lançamento.

\begin{tabular}{|c|c|c|c|c|}
\hline \multirow{2}{*}{ Parâmetro } & \multicolumn{4}{|c|}{ Padrões de Lançamento de Efluentes em Corpos Hídricos (mg/L) } \\
\hline & Muito Restritivo & Restritivo & Menos Restritivo & Não Adota \\
\hline \multirow{2}{*}{$\begin{array}{c}\text { DQO } \\
\left(\mathrm{mg} \mathrm{O}_{2} / \mathrm{L}\right)\end{array}$} & $\mathrm{C}<120$ & $120 \leq C \geq 200$ & $>200$ & - \\
\hline & $A M, P E^{(1)}$ & $\begin{array}{c}\mathrm{AM}, \mathrm{AL}, \mathrm{CE}, \mathrm{PE}, \mathrm{ES}, \mathrm{MG}, \\
\mathrm{PR}, \mathrm{RS}^{(2)}\end{array}$ & $\mathrm{PE}(1), \mathrm{MG}, \mathrm{PR}, \mathrm{RS}^{(2)}$ & $\begin{array}{c}\text { RO, BA, MA, GO, MS, RJ, } \\
\text { SP, SC }\end{array}$ \\
\hline \multirow{2}{*}{$\begin{array}{c}\text { DBO } \\
\left(\mathrm{mg} \mathrm{O}_{2} / \mathrm{L}\right)\end{array}$} & $<60$ & $60 \leq C \geq 90$ & $>90$ & - \\
\hline & $P E^{(1)}, R J^{(1)}, P R, R S^{(2)}$ & $\begin{array}{c}A M, A L, P E^{(1)}, G O, M G, R J^{(1)} \\
\text { SP, PR, } R^{(2)}, S C\end{array}$ & $C E, P E{ }^{(1)}, M S, R J^{(1)}, P R, R^{(2)}$ & RO, BA, MA, ES \\
\hline \multirow{2}{*}{$\begin{array}{c}\text { SST } \\
(\mathrm{mg} / \mathrm{L})\end{array}$} & $<100$ & $100 \leq C \geq 150$ & $>150$ & - \\
\hline & $A M, R J^{(1)}, R^{(2)}$ & $A M, C E^{(3)}, E S, M G, R^{(1)}, R^{(2)}$ & $\mathrm{RJ}^{(1)}, \mathrm{RS}^{(2)}$ & $\begin{array}{l}\text { RO, AL, BA, MA, PE, GO, } \\
\text { MS, SP, PR, SC }\end{array}$ \\
\hline \multirow{2}{*}{$\begin{array}{l}\text { N Total } \\
(\mathrm{mg} / \mathrm{L})\end{array}$} & $<10$ & $10 \leq C \geq 20$ & $>20$ & - \\
\hline & - & $\mathrm{RJ}^{(1)}, \mathrm{RS}^{(2)}, \mathrm{SC}$ & - & $\begin{array}{l}\text { AM, RO, AL, BA, CE, MA, } \\
\text { PE, GO, MS, ES, MG, SP, PR }\end{array}$ \\
\hline \multirow{2}{*}{$\underset{(\mathrm{mg}-\mathrm{N} / \mathrm{L})}{\mathrm{NH}_{3}}$} & $<5$ & $5 \leq \mathrm{C} \geq 20$ & $>20$ & - \\
\hline & $A L$ & $\begin{array}{c}\mathrm{RO}, \mathrm{CE}^{(4)}, \mathrm{MS}, \mathrm{ES}, \mathrm{MG}, \\
\mathrm{RJ}, \mathrm{RS}\end{array}$ & - & $\begin{array}{l}\text { AM, BA, MA, PE, GO, SP, } \\
\text { PR, SC }\end{array}$ \\
\hline \multirow[b]{2}{*}{ P Total (mg/L) } & $<1$ & 1 & $>1$ & - \\
\hline & - & RJ, RS (2) & $\mathrm{SC}, \mathrm{RS}^{(2)}$ & $\begin{array}{l}\text { AM, RO, AL, BA, CE, MA, } \\
\text { PE, GO, MS, ES, MG, SP, PR }\end{array}$ \\
\hline \multirow{2}{*}{$\begin{array}{c}\text { C Term } \\
\text { (NMP/100mL) }\end{array}$} & $<10^{4}$ & $10^{4} \leq C \geq 10^{5}$ & $>10^{5}$ & - \\
\hline & CE & $\mathrm{PE}, \mathrm{RS}^{(2)}$ & $\mathrm{BA}, \mathrm{PE}, \mathrm{RS}^{(2)}$ & $\begin{array}{c}\text { AM, RO, AL, MA, GO, MS, } \\
\text { ES, MG, RJ, SP, PR, SC }\end{array}$ \\
\hline
\end{tabular}

1. Em Função da Carga Orgânica Bruta (kg/dia).

2. Em Função da Vazão Diária de Lançamento ( $\left.\mathrm{m}^{3} / \mathrm{dia}\right)$.

3. Limites diferentes de acordo com o tipo de efluente (sanitário, industrial, provenientes de lagoas de estabilização).

4. Limites diferentes de acordo com o pH.

\subsection{Padrões de Reúso para Águas Residuárias Tratadas}

Os estados do Ceará e de São Paulo apresentam-se como pioneiros no desenvolvimento de legislações sobre padrões para reúso de água a partir de esgotos sanitários. Não foram identificadas legislações de outros estados. A Resolução Coema $n^{\circ}$ 02/2017, do Ceará, estabelece padrões para reúso de água a partir de efluentes sanitários, abrangendo quatro modalidades, como retratado na Tabela 7.

Essa legislação também permite reúso externo de efluentes não sanitários, como os efluentes provenientes de processos industriais, desde que seja apresentado projeto prévio ao órgão ambiental competente e que obedeça aos padrões de reúso de água de acordo com as modalidades previstas na legislação.

A Resolução Conjunta SES/SMA/SSRH n ${ }^{\circ}$ 01/2017, do estado de São Paulo, disciplina o reúso direto não potável de água para fins urbanos, como irrigação paisagística, lavagem de logradouros públicos, construção civil e lavagem de veículos. Estabelece duas categorias de reúso, a saber, uso com restrição moderada e uso com restrição severa, de acordo com o grau de restrição ao contato humano. Dessa forma, a categoria com restrição severa possui parâmetros de qualidade menos restritos, mas possui maiores restrições de uso para evitar o contato da água de reúso com o homem.

Essa legislação apresenta-se como pioneira ao definir padrões de qualidade utilizando parâmetros de DBO, turbidez, SST, cloro residual, cloreto, boro e Razão de Adsorção de Sódio (RAS), além dos convencionais adotados no estado do Ceará.

Nesse contexto, essas legislações fornecem fundamento legal para o desenvolvimento de mais projetos de reúso de água, contribuindo também para fomentar ações de engenharia sanitária e ambiental nos estados brasileiros. 
Tabela 7 - Padrões da Resolução Coema n 02/2017 para Reúso de Efluentes Sanitários.

\begin{tabular}{|c|c|c|c|c|c|c|}
\hline \multirow[b]{2}{*}{ Parâmetro } & \multicolumn{6}{|c|}{ Parâmetros } \\
\hline & $\begin{array}{c}\text { C Term } \\
\text { (NMP/ 100mL) }\end{array}$ & $\begin{array}{l}\text { Ovos de } \\
\text { Geohelminto } \\
\text { (ovo/L) }\end{array}$ & $\begin{array}{c}\text { C.E } \\
(\mu \mathrm{S} / \mathrm{cm})\end{array}$ & pH & $\begin{array}{c}\text { Temperatura } \\
\left({ }^{\circ} \mathrm{C}\right)\end{array}$ & $\begin{array}{c}\text { RAS } \\
\left(\mathrm{mmolcL}^{-1}\right)\end{array}$ \\
\hline Urbanas & $\begin{array}{c}5000 \\
1000^{(1)}\end{array}$ & 1 & 3000 & $6,0-8,5$ & - & - \\
\hline $\begin{array}{l}\text { Agrícolas e } \\
\text { Florestais }\end{array}$ & $\begin{array}{l}\mathrm{ND}^{(2)(3)} \\
1000^{(4)}\end{array}$ & $\begin{array}{l}\mathrm{ND}{ }^{(1)} \\
1^{(3)}\end{array}$ & 3000 & $6,0-8,5$ & - & 15 \\
\hline Ambientais & 10.000 & 1 & 3000 & $6,0-8,5$ & - & - \\
\hline Aquicultura & 1000 & ND & 3000 & $6,0-8,0$ & 40 & - \\
\hline
\end{tabular}

1. Para fins de irrigação paisagística.

2. ND: Não Detectável.

3. Culturas a serem consumidas cruas cuja parte consumida tenha contato direto com a água de irrigação.

4. Demais culturas.

A Tabela 8 apresenta uma comparação dessas legislações com as recomendações da Organização Mundial da Saúde (OMS), da Agência de Proteção Ambiental dos Estados Unidos (USEPA), da Pesquisa em Saneamento Básico (Prosab) e da NBR 13.969/1997, a qual dispõe sobre a disposição final dos efluentes líquidos de tanque séptico.

Para a modalidade urbana, o padrão de coliformes termotolerantes estabelecido na legislação cearense apresenta-se menos restrito em relação à ABNT NBR 13.969/1997, inclusive para a atividade de irrigação paisagística. Destaca-se que a USEPA e a legislação do estado de São Paulo estabelecem um exigência muito rigorosa para essa modalidade de reúso, não admitindo a detecção de coliformes termotolerantes em águas de reúso para as atividades urbanas em que possa ocorrer contato de água com o homem.

A Resolução Coema n 02/2017 do Ceará e a OMS estabelecem a mesma concentração máxima de coliformes termotolerantes para irrigação paisagística, 1.000 NMP/100 mL, mas, para atividades em que ocorra contato direto com o público, a OMS indica um padrão mais restritivo de 200 NMP/100 mL, assim como a legislação de São Paulo.
Em relação às atividades agrícolas e florestais, a legislação cearense apresenta-se muito restritiva quanto à presença de coliformes termotolerantes nos efluentes tratados para irrigação de culturas alimentares a serem consumidas cruas cuja parte consumida tenha contato direto com a água de irrigação, seguindo o mesmo padrão adotado pelas USEPA. Para a irrigação de demais culturas, o limite de coliformes termotolerantes torna-se mais restritivo em relação às recomendações do Prosab e da NBR 13.969/1997 e menos restritivo em comparação com as diretrizes da USEPA. Os padrões utilizados para coliformes para as outras modalidades de reúso são similares.

No que concerne à detecção de ovos de helmintos, a USEPA apresenta diretrizes muito restritivas, e as outras fontes de estudo estabelecem padrões menos restritivos. Ressalta-se que, apesar de a qualidade microbiológica das águas de reúso dever assegurar a saúde da população, a adoção de padrões muito rigorosos pode dificultar a prática de reúso de água devido, principalmente, aos elevados custos de tratamento a serem empregados. Uma ferramenta que pode ser de grande valia nessa tomada de decisão é a Análise Quantitativa de Risco Microbiológico (AQRM, QMRA no inglês), a qual não é prevista ou sugerida em nenhuma legislação nacional. 
Tabela 8 - Comparação entre os padrões de reúso adotados pelas legislações estaduais brasileiras com outras fontes disponíveis.

\begin{tabular}{|c|c|c|c|c|c|c|c|c|c|c|c|c|c|c|c|c|}
\hline \multicolumn{17}{|c|}{$\begin{array}{c}\text { PADRÕES DE REÚSO DE ÁGUAS } \\
\text { CONCENTRAÇÕES EXIGIDAS NOS EFLUENTES }\end{array}$} \\
\hline \multirow{2}{*}{$\begin{array}{c}\text { Parâmetro } \\
\text { Modalidade } \\
\text { de reúso }\end{array}$} & \multicolumn{4}{|c|}{$\begin{array}{l}\text { C Term } \\
\text { (NMP/ } 100 \mathrm{~mL})\end{array}$} & \multicolumn{4}{|c|}{$\begin{array}{c}\text { Ovos de Helmintos } \\
\text { (ovo/L) }\end{array}$} & \multicolumn{4}{|c|}{$\begin{array}{c}\text { C.E } \\
(\mu \mathrm{S} / \mathrm{cm})\end{array}$} & \multicolumn{4}{|c|}{$\mathrm{pH}$} \\
\hline & F.Ur $r^{(1)}$ & $\mathbf{F} \cdot \mathbf{A g}^{(2)}$ & F. $A^{(3)}$ & $\mathrm{F} . \mathrm{Aq}^{(4)}$ & F.Ur & F.Ag & F.A & F.Aq & F.Ur & F.Ag & F.A & F.Aq & F.Ur & F.Ag & F.A & F.Aq \\
\hline $\begin{array}{c}\text { CE - } \\
\text { Resolução } \\
\text { Coema } \\
02 / 2017\end{array}$ & $\begin{array}{c}5000 \\
1000^{(5)}\end{array}$ & $\begin{array}{l}\mathrm{ND}^{(6)(7)} \\
1000^{(8)}\end{array}$ & 10.000 & 1000 & 1 & $\begin{array}{l}N D \\
(6)(7) \\
1^{(8)}\end{array}$ & 1 & ND & 3000 & 3000 & 3000 & 3000 & $6,0-8,5$ & $6,0-8,5$ & $6,0-8,5$ & $6,0-8,0$ \\
\hline $\begin{array}{c}\text { SP - } \\
\text { Resolução } \\
\text { SES/SMA/ } \\
\text { SSRH } \\
01 / 2017\end{array}$ & $\begin{array}{l}\mathrm{ND}^{(12)} \\
<200^{(13)}\end{array}$ & - & - & - & $\begin{array}{l}<1^{(12)} \\
1^{(13)}\end{array}$ & - & - & - & $\begin{array}{l}700^{(12)} \\
3000^{(13)}\end{array}$ & - & - & - & $\begin{array}{l}6,0-9,0^{(12)} \\
6,0-9,0^{(13)}\end{array}$ & - & - & - \\
\hline $\begin{array}{c}\text { Prosab } \\
\text { (Mota 2007) }\end{array}$ & - & $\begin{array}{c}1000^{(7)} \\
10000^{(8)}\end{array}$ & - & $\begin{array}{l}10000^{(10)} \\
1000^{(11)}\end{array}$ & - & 1 & - & 1 & - & - & - & - & - & - & - & - \\
\hline $\begin{array}{c}\text { USEPA } \\
\text { Guidelines } \\
\text { for Water } \\
\text { Reuse. } 2012\end{array}$ & $\begin{array}{l}\mathrm{ND}^{(5)(12)} \\
200^{(13)}\end{array}$ & $\begin{array}{l}\mathrm{ND}^{(6)(7)} \\
200^{(8)}\end{array}$ & 200 & - & $N D^{(5)}$ & $N D^{(7)}$ & - & - & - & - & - & - & $6,0-9,0$ & $6,0-9,0$ & - & - \\
\hline $\begin{array}{l}\text { ABNT NBR } \\
13.969 / 97\end{array}$ & $\begin{array}{c}200 \\
500^{(5)}\end{array}$ & $5000^{(8)}$ & - & - & - & - & - & - & - & - & - & - & $6,0-8,0$ & - & - & - \\
\hline
\end{tabular}

1. Reúso para fins urbanos.

2. Reúso para fins agrícolas e florestais.

3. Reúso para fins ambientais.

4. Reúso para fins de aquicultura.

5. Para Irrigação Paisagística.

6. ND: Não Detectável.

7. Irrigação Irrestrita. Culturas a serem consumidas cruas cuja parte consumida tenha contato direto com a água de irrigação.

8. Irrigação Restrita. Demais culturas.

9. Um valor mais restritivo é apropriado para gramados públicos, tais como hotéis, com os quais o público tenha contato direto.

10. Afluentes do tanque de piscicultura.

11. No tanque de piscicultura.

12. Para atividades urbanas em que o contato com a água não é restrito.

13. Para atividades urbanas em que o contato com a água é restrito.

Dessa forma, percebe-se que os padrões adotados pela Resolução Coema n 02/2017 do Ceará são mais realistas para o contexto socioeconômico dos estados brasileiros, os quais, em comparação com os estados norte-americanos, possuem menos acesso a tecnologias avançadas de tratamento de efluentes e a recursos financeiros destinados a essa finalidade.

\section{CONCLUSÕES}

Por meio da análise dos padrões de lançamento de efluentes, percebeu-se a diversidade na forma de abordagem dos limites, seja em termos de concentração ou carga poluidora, não se ob- servando uma uniformização na adoção dos padrões de lançamento.

Por meio do estabelecimento dos níveis de restrição, constatou-se que alguns estados mantêm uma postura muito restritiva, dificultando o cumprimento da legislação devido ao alto nível de tratamento requerido para alcançar determinado padrão.

Percebe-se que alguns estados suprimem a responsabilidade das Companhias e Agências de tratamento de esgotos públicos, mas exigem das indústrias e de outros empreendimentos privados o cumprimento do padrão de nitrogênio amoniacal. Essa medida apresenta-se contraditória em termos de geração de impacto ambiental, pois é notável que os esgotos públicos tratados corres- 
pondem a uma elevada parcela da carga poluidora lançada em mananciais, principalmente devido à elevada vazão de descarte.

Adicionalmente, alguns estados consentem padrões menos restritivos. Nesse caso, a carga poluidora deve ser analisada para que o lançamento dos efluentes não venha a provocar degradação do corpo receptor.

\section{Constatou-se que apenas os estados do Ceará e} de São Paulo possuem legislações sobre padrões de qualidade para reúso de águas residuárias, o que representa um avanço na legalização das práticas de reúso e um estímulo para a adoção de padrões próprios por outros estados. Entretanto, verifica-se a falta de um marco regulatório legal, em nível nacional, que estabeleça padrões e diretrizes que conduzam essa prática.

\section{REFERÊNCIAS}

ALAGOAS. Decreto $n^{\circ}$ 6.200, de 01 de Março de 1985. Estabelece medidas de proteção ambiental na área de implantação do Pólo Cloroquímico de Alagoas e dá outras providências. AL. 1985.

ASSOCIAÇÃO BRASILEIRA DE NORMAS TÉCNICAS. NBR 13.969: Tanques sépticos - Unidades de tratamento complementar e disposição final dos efluentes líquidos - Projeto, construção e operação. RJ. 1997.

BAHIA. Conselho Estadual de Meio Ambiente (Cempram). Resolução $n^{\circ} 2.288$, de 28 de Abril de 2000. Aprova a Norma Técnica NT 002/2000, que estabelece os padrões de lançamento para efluentes sanitários nos corpos hídricos situados na Região Metropolitana de Salvador - RMS e demais municípios do Estado da Bahia, gerados a partir da implantação de empreendimentos imobiliários habitacionais. BA. 2000.

BRASIL. Conselho Nacional do Meio Ambiente (Conama). Resolução n 357, de 17 de Março de 2005. Dispõe sobre a classificação dos corpos de água e diretrizes ambientais para o seu enquadramento, bem como estabelece as condições e padrões de lançamento de efluentes, e dá outras providências. Diário Oficial da República Federativa do Brasil. Brasília. DF. 2005.

BRASIL. Conselho Nacional do Meio Ambiente (Conama). Resolução $n^{\circ}$ 430, de 13 de Maio de 2011. Dispõe sobre as condições e padrões de lançamento de efluentes, completa e altera a Resolução $n^{\circ} 357$, de março de 2005, do Conselho Nacional do Meio Ambiente - Conama. Diário Oficial da República Federativa do Brasil. Brasília. DF. 2011.
CEARÁ. Conselho Estadual do Meio Ambiente (Coema). Resolução $\mathrm{n}^{\circ}$ 02, de 02 de Fevereiro de 2017. Dispõe sore os padrões e condições para lançamento de efluentes líquidos gerados por fontes poluidoras. CE. 2017.

DISTRITO FEDERAL. Decreto $n^{\circ}$ Decreto $n^{\circ} 18.328$, de 08 de Junho de 1997. Altera o Decreto ${ }^{\circ} 5.631$, de 27 de novembro de 1990, que aprova o novo Regulamento para Instalações Prediais de Esgotos Sanitários no Distrito Federal, que com esta baixa, e dá outras providências. DF. 1997.

ERICKSON, R.J. An evaluation of mathematical models for the effects of $\mathrm{pH}$ and temperature on ammonia toxicity to aquatic organisms. Water Research, n. 19, p. 1047-1058, 1985.

GOIÁS. Companhia de Desenvolvimento Econômico de Goiás (Codego). Regulamento CODEGO-AGE de 08 de Julho de 2016. Define padrões de lançamento na rede coletora para indústrias localizadas nos distritos industriais de Goiás. 2016.

GOIÁS. Decreto Estadual n 1.745, de 06 de Dezembro de 1979. Aprova o Regulamento da Lei ${ }^{\circ} 8.544$, de 17 de outubro de 1978, que dispõe sobre a prevenção e o controle da poluição do meio ambiente. GO. 1979.

HESPANHOL, I. Potencial de reúso de água no Brasil: agricultura, indústria, municípios, recarga de aquíferos. Revista Brasileira de Recursos Hídricos, v. 07, n. 4, p. 75-95. 2003.

JORDÃO, E. P; VOLSCHAN JR, I. Tratamento de esgotos sanitários em empreendimentos habitacionais. Brasília: CAIXA, 2009.

MANAUS (AMAZÔNIA). Conselho Municipal de Desenvolvimento e Meio Ambiente (Comdema). Resolução n 34, de 27 de Julho de 2012. Estabelece normas e padrões para qualidade das águas, condições para lançamento de efluentes e dá outras providências. Manaus, AM. 2012.

MARANHÃO. Secretaria de Estado de Meio Ambiente e Recursos Naturais (Sema). Portaria n 79, de 04 de Julho de 2013. São Luís. MA. 2013.

MATO GROSSO DO SUL. Conselho Estadual de Controle Ambiental (Ceca). Deliberação n 36, de Junho de 2012. Dispõe sobre a classificação dos corpos de água superficiais e estabelece diretrizes ambientais para o seu enquadramento; bem como, estabelece as diretrizes, condições e padrões de lançamento de efluentes no âmbito do Estado do Mato Grosso do Sul, e dá outras providências. MS. 2012.

MINAS GERAIS. Conselho Estadual de Política Ambiental (Copam). Conselho Estadual de Recursos Hídricos do Estado de Minas Gerais (CERH). Deliberação Normativa Conjunta COPAM/CERH n 01 , de 05 de Maio de 2008. Dispõe sobre a classificação dos corpos hídricos e diretrizes ambientais para o seu enquadramento, bem como, estabelece as condições e padrões de lançamento de efluentes, e dá outras providências. MG. 2008.

MOTA, S. et al. Reúso de águas em irrigação e piscicultura. 2007. 
PARANÁ. Conselho Estadual do Meio Ambiente (Cema). Resolução $\mathrm{n}^{\circ}$ 70, de 01 de Outubro de 2009. Dispõe sobre o licenciamento ambiental, estabelece condições e critérios e dá outras providências para empreendimentos industriais. PR. 2009.

PARANÁ. Secretaria de Estado de Meio Ambiente e Recursos Hídricos (Sema). Resolução n 21, de 22 de Abril de 2009. Dispõe sobre licenciamento ambiental, estabelece condições e padrões ambientais e dá outras providências, para empreendimentos de saneamento. PR. 2009.

PERNAMBUCO. Agência Estadual de Meio Ambiente (CPRH). Norma Técnica $n^{\circ} 2.001$. Controle de carga orgânica em efluentes líquidos industriais - estabelece critérios e padrões de emissão que resultem na redução da carga industrial lançada direta ou indiretamente nos recursos hídricos do estado de Pernambuco. PE. 2001.

PERNAMBUCO. Agência Estadual de Meio Ambiente (CPRH). Norma Técnica $n^{\circ}$ 2.002. Avaliação de parâmetros para descarga de efluentes líquidos industriais e domésticos. PE. 2002.

PERNAMBUCO. Agência Estadual de Meio Ambiente (CPRH). Norma Técnica $n^{\circ} 2.007$. Coliformes termotolerantes - Padrões de Lançamento para efluentes domésticos e/ou industriais - estabelecer o NMP máximo de coliformes termotolerantes (CTer) permitidos para lançamento de efluentes domésticos ou industriais nos corpos de água receptores. PE. 2007.

REIS, J.A.T. Análise dos padrões para os compostos amoniacais segundo a Resolução CONAMA 20/86. Revista de Engenharia Sanitária e Ambiental, v. 3, n. 4, p. 146-154, 1998.

REIS, J.A.T.; MENDONÇA, A.S.F. Amônia em efluentes e mananciais de água doce - Uma avaliação dos limites impostos pelo CONAMA. In: CONGRESSO BRASILEIRO DE ENGENHARIA SANITÁRIA AMBIENTAL, 20, 1997, Anais..., Rio de Janeiro: ABES, 1999A.

REIS, J.A.T.; MENDONÇA, A.S.F. A influência dos valores de pH e temperatura sobre a toxicidade da amônia e sua importância na definição de padrões ambientais para corpos d'água. In: CONGRESSO BRASILEIRO DE ENGENHARIA SANITÁRIA AMBIENTAL, 20, 1997, Anais..., Rio de Janeiro: Associação Brasileira de Engenharia Sanitária e Ambiental - Abes, 1999B.

REIS, J.A.T.; MENDONÇA, A.S.F. Análise técnica dos novos padrões brasileiros para amônia em efluentes e corpos d'água. Revista de Engenharia Sanitária e Ambiental, v. 14, n. 3, p. 353-362, 2009.

RIO DE JANEIRO. Fundação Estadual de Engenharia do Meio Ambiente (FEEMA). Norma Técnica 202.R-10, de 1986. Estabelece critérios e padrões para lançamento de efluentes líquidos, como parte integrante do Sistema de Licenciamento de Atividades Poluidoras-SLAP. RJ. 1986.

RIO DE JANEIRO. Fundação Estadual de Engenharia do Meio Ambiente (FEEMA). Norma Técnica 215.R-4, de 2007. Diretriz de controle de carga orgânica biodegradável em efluentes líquidos de origem sanitária - estabelece exigências de controle de poluição das águas que resultem na redução de carga orgânica biodegra- dável de origem sanitária, como parte integrante do Sistema de Licenciamento de Atividades Poluidoras - SLAP. RJ. 2007.

RIO GRANDE DO SUL. Conselho Estadual do Meio Ambiente (Consema). Resolução $n^{\circ}$ 128, de 07 de Dezembro de 2006. Dispõe sobre a fixação de padrões de emissão de efluentes líquidos para fontes de emissão que lancem seus efluentes em águas superficiais no estado do Rio Grande do Sul. RS. 2006.

RONDÔNIA. Secretaria de Estado do Desenvolvimento Ambiental (Sedam). Decreto $n^{\circ} 7.903$ de 01 de Julho de 1997. Regulamenta a Lei $n^{\circ} 547$, de 30 de dezembro de 1993, que dispõe sobre proteção, recuperação, controle, fiscalização da qualidade do meio ambiente no Estado de Rondônia. RO. 1997.

SANTA CATARINA. Decreto Estadual $n^{\circ} 14.250$, de 05 de Junho de 1981. Regulamenta dispositivos da Lei $n^{\circ} 5.793$, de 15 outubro de 1980 , referentes à proteção e a melhoria da qualidade ambiental. SC. 1981.

SANTA CATARINA. Lei Estadual n 14.675, de 13 de Abril de 2009. Institui o Código Estadual do Meio Ambiente e estabelece outras providências. SC. 2009.

SÃO PAULO. Decreto Estadual $\mathrm{n}^{\circ}$ 8.468, de 08 de Setembro de 1976. Aprova o Regulamento da Lei $n^{\circ} 997$, de 31 de maio de 1976, que dispõe sobre a prevenção e o controle da poluição do meio ambiente. SP. 1976.

SÃO PAULO. Resolução Conjunta SES/SMA/SSR n ${ }^{\circ} 01$, de 28 de Junho de 2017. Disciplina o reúso direto não potável de água, para fins urbanos, proveniente de Estações de Tratamento de Esgoto Sanitário e dá outras providências. SP. 2017.

UNITED STATES ENVIRONMENTAL PROTECTION AGENCY (USEPA). Guidelines for water reuse. 2012.

VEROL, A. P. VOLSCHAN JR, I. Inventário e Análise de Padrões de Lançamento de Esgotos Sanitários: Visão Nacional e Internacional. XVII Simpósio Brasileiro de Recursos Hídricos. 2011.

VITÓRIA (ESPÍRITO SANTO). Conselho Municipal de Defesa do Meio Ambiente de Vitória (COMDEMA). Resolução nº 02, de 1991. Estabelece critérios e padrões para o controle da poluição dos recursos hídricos no município de Vitória. Vitória, ES. 1991.

VON SPERLING, M. Análise dos padrões brasileiros de qualidade de corpos d'água e de lançamento de efluentes líquidos. Revista Brasileira de Recursos Hídricos, v.3, n 1, p. 111-132, 1998.

VON SPERLING, M. Princípios do Tratamento Biológico de Águas Residuárias. Vol. 1. Introdução à qualidade das águas e ao tratamento de esgotos. $3^{\circ}$ edição. Belo Horizonte: Departamento de Engenharia Sanitária e Ambiental; UFMG. 2005.

VON SPERLING, M., NASCIMENTO, L.V. A resolução CONAMA 20/86 e as legislações estaduais de classificação das águas e lançamento de efluentes. In: Anais do $20^{\circ}$ Congresso Brasileiro de Engenharia Sanitária e Ambiental, Rio de Janeiro, p. 24132419, 1999. 